\title{
NILAI PROFETIK TRANSENDENSI DALAM NOVEL SEMUA IKAN DI LANGIT KARYA ZIGGY ZEZSYAZEOVIENNAZABRIZKIE
}

\author{
Ida Komalasari \\ STKIP PGRI Banjarmasin \\ Jalan Sultan Adam, Komplek H. Iyus, No. 18 RT.23 Banjarmasin \\ Kalimantan Selatan. Kode pos 70121, \\ email: idakomalasari56@gmail.com
}

\begin{abstract}
ABSTRAK
Penelitian ini bertujuan mendeskripsikan nilai profetik trasendensi dalam novel Semua Ikan di Langit karya Ziggy Zezsyazeoviennazabrizkie. Penelitian dan pembahasan ini menggunakan pendekatan strukturalisme-dinamik dengan menggunakan teknik analisis data hermeneutik. Adapun hasil penelitian yang diperoleh yaitu mengungkapkan dan mendeskrispikan aspek transendesi sebagai berikut. Pertama, pengakuan tentang ketergantungan manusia kepada Tuhan tampak melalui perasaan dan keyakinan tang terdapat dalam diri manusia. Kedua, ada perbedaan mutlak antara Tuhan dan manusia yang ditandai dengan pengakuan keterbatasan diri manusia serta kesempurnaan yang dimiliki Tuhan. Ketiga, pengakuan akan adanya norma-norma mutlak dari Tuhan yang tidak berasal dari manusia melalui kepatuhan dan ketaatan manusia terhadap ketetapan dari Tuhan.
\end{abstract}

Kata Kunci: nilai, profetik, transendensi

\section{PENDAHULUAN}

Karya sastra yang hingga saat ini dapat terus diterima masyarakat karena memiliki sifat reflektif. Sifat reflektif ini memberikan keleluasaan sebagai sarana bagi individu untuk merumuskan pengalaman batin yang rumit ke dalam persoalan-persoalan yang menghasilkan makna dan ruh yang lebih sejati (Sugiarti, 2016; Sugiarti, 2015).

Karya sastra sebagai salah satu produk budaya karena mampu memenuhi kebutuhan masyarakat yang dihasilkan melalui proses penciptaan secara kreatif dan imajinatif. Kebutuhan tersebut diungkapkan melalui ekspresi narasi persuasif dan informatif yang dapat mempengaruhi pembacanya, khusunya dalam pemenuhan kehidupan bersifat kerohanian atau keagamaan.

Karya sastra berbentuk prosa dan fiksi yang bernuansa Islam telah memberikan wacana baru bagi perkembangan sastra Indonesia (Efendi, 2012). Melalui keberadaan karya sastra Islami ini memberikan ruang kepada penulis sebagai alternatif dakwah dengan mengajarkan nilai-nilai serta ajaran Islam sekaligus sebagai sarana pembelajaran bagi masyarakat dengan proses kreatif. 
Misi utama estetika profetik dalam karya sastra yaitu berusaha menyentuh perasaan terdalam manusia dengan tujuan menyadarkan sehingga membentuk perilaku religius. Karya sastra mengandung unsur kesastraan yang dapat dimanfaatkan oleh manusia dalam kehidupan manusia, terlebih lagi dalam perkembangannya nilai kesastraan tidak hanya bertujuan rekreatif tetapi mampu memberikan pengalaman religi kepada pembacanya. Efendi (2012) mengungkapkan bahwa karya sastra semacam ini berada diantara wilayah estetika dan etika atau dogma yang mampu menciptakan norma-norma dengan bantuan estetika.

Berdasarkan hal tersebut maka norma-norma agama atau petunjuk ajaran agama dapat ditemui dalam karya sastra dengan dibalut oleh nilai estetika berupa runtutan bahasa-bahasa yang memiliki keindahan serta mampu menggerakkan jiwa manusia sebagai mahkluk beragama. Sejalan dengan hal tersebut, maka estetika memegang kunci utama dalam karya sastra sebagai keindahan dan penalaran yang menggunakan simbol dan dapat dimanfaatkan oleh pembaca (Wulananda, Saryono, dan Suwignyo: 2016: 1350; Endraswara, 2012: 100)

Sastra profetik merupakan salah satu alat yang digunakan untuk mengkaji karya sastra melalui perspektif religi atau keagamaan, khususnya yang bersumber dari agama Islam. Kemunculan sastra profetik yaitu dilandasi oleh maraknya novel yang bernuansa Islam yang memunculkan muatan-muatan moral religius yang dapat dimanfaatkan masyarakat sebagai makhluk beragama. Wulananda, Saryono, dan Suwignyo (2016: 1351), menyatakan bahwa karya sastra profetik berusaha menyeimbangkan antara tema sosial dan spiritual yang merepresentasikan sejarah kemanusiaan maupun nilai-nilai kenabian atau agama dengan mempertimbangkan unsur estetika.

Nilai keagamaan dalam karya sastra profetik yang mengandung unsur-unsur ketuhanan dalam dimensi sosial dan dimensi transendental. Sastra profetik dicanangkan kembali oleh kuntowijoyo dengan pandangan-pangadangan yang lebih berterima oleh masyarakat yang terdapat dalam karya sastra. Kuntowijoyo (2006: 20), mengemukakan aspek profetik yang ditemukan melalui Surah AlImran ayat 110 yang kemudian dilakukan pengkritalisasian menjadi tiga aspek yaitu amar ma'ruf berupa humanisasi (menyuruh kebaikan), nahi mungkar berupa liberasi (mencegah kejahatan), dan tu'minuna billah berupa transendensi (beriman kepada Tuhan).

Aspek transendensi menjadi komponen yang paling penting dalam membentuk keribadian dan individual sebagai mahkluk beragama yang meyakini adanya keberadaan dan kekuasaan Tuhan. Efendi (2012) menyatakan bahwa sumber-sumber penemuan jati diri manusia kembali dan penyebab tumbuhnya kemungkinan-kemungkinan transendental. Transendensi sebenarnya tidak hanya mencakup aspek ketuhanan dalam lingkup beragama, tetapi lebih jauh merupakan 
pemaknaan dalam diri guna mencapai batasan pengetahuan dan kemampuan manusia, sehingga lebih menyadari keberadaan dirinya secara material.

Unsur transendental dalam sastra profetik berupa mengungkapkan kesadaran manusia sebagai makhluk beragama. Garaudy (2000: 34), mengungkapkan unsur transendensi sebagai tiga bagian yaitu pengakuan tentang ketergantungan manusia kepada Tuhan, ada perbedaan mutlak anatara Tuhan dan manusia, dan pengakuan akan adanya norma-norma mutlak dari Tuhan yang tidak berasal dari akal manusia.

Novel bernuasa Islami telah menjadi populer di Indonesia bahkan diantaranya mampu menjadi fenomena dalam masyarakat. Unsur bahasa yang religi yang secara denotatif sehingga memudahkan pembaca dan memberikan pengalaman transendensi dalam beragama. Namun, saat ini penulis semakin berlomba-lomba untuk dapat memanfaatkan bahasa yang kreatif sehingga mampu menciptakan bahasa yang konotatif dalam menyampaikan gagasan. Dewan Kesenian Jakarta dalam ajang lomba penulisan novel semakin menaikkan level kerativitas penulis agak menghasilkan karya sastra yang berkualitas tidak hanya dari segi muatan moral tetapi melalui perspektif bahasa yang berkompeten.

Salah satu novel yang berhasil mencuri perhatian para juri dalam dewan kesesian Jakarta adalah novel Semua Ikan di Langit karya Ziggy Zezsyazeoviennazabrizkie yang berhasil meraih juara pertama pada Sayembara Menulis Novel Dewan Kesenian Jakarta tahun 2016. Kualitas novel karya Ziggy ini memikat dewan juri sehingga tidak ada pemenang kedua dan ketiga pada sembara tahun 2016 tersebut. Para dewan juri menyampaikan bahwa novel Semua Ikan di Langit merupakan naskah yang mampu merekahkan situasi miris dan manis dalam waktu bersamaan.

Berdasarkan pemaparan tersebut, menarik untuk dikaji bagaimana profetik dalam aspek transendensi sebagai penanda utama sastra Islami yang terdapat dalam novel Semua Ikan di Langit oleh Ziggy Zezsyazeoviennazabrizkie. bagaimanakan pengungkapan aspek transendensi sebagai realitas profetik yang dihubungkan dengan keberadaan realitas manusia modern sebagai makhluk beragama.

\section{METODE}

Sumber data penelitian ini adalah novel Semua Ikan di Langit yang ditervitkan oleh Gramedia pada tahun 2017 dengan jumlah 259 halaman. Deskripsi secara simbol kebahasaan yang terdapat dalam novel berupaya menjelaskan adanya aspek transendensi yang menjadi data 
penelitian. Dengan demikian data pada penelitian ini berkaitan dengan fokus penelitian berupa aspek transendensi yang terdapat dalam novel.

Data pada penelitian ini adalah kutipan satuan cerita berupa satuan bahasa berwujud kata, frasa, kalimat dan wacana yang berkaitan dengan fokus penelitian. Data diperoleh melalui hasil analisis dengan penginterpretasian yang disajikan dalam bentuk uraian deskripsi serta disimpulkan berdasarkan fokus penelitian. kegiatan analisis data dilakukan dengan cara pembacaan secara intensif untuk menenukan aspek transendensi dalam novel Semua Ikan di Langit. Tahap selanjutnya yaitu melakukan interpretasi atas data yang telah diperoleh yang berkaitan dengan fokus penelitian.

\section{HASIL DAN PEMBAHASAN}

\section{Hasil}

Sesuai dengan hasil penelitian, dalam bagian ini akan menjelaskan pembahasan mengenai transendensi yang terdapat dalam novel Semua Ikan di Langit Karya Ziggy Zezsyazeoviennazabrizkie pembahasan yang disajikan mencakup tiga aspek (a) pengakuan tentang ketergantungan manusia kepada Tuhan, (b) ada perbedaan mutlak antara Tuhan dan manusia, dan (c) pengakuan akan adanya norma-norma mutlak dari Tuhan yang tidak berasal dari akan manusia.

\section{Pengakuan Tentang Ketergantungan Manusia Kepada Tuhan}

Manusia pada dasarnya memiliki ketergantungan kepada Tuhan, sebab hanya Tuhan yang berkuasa atas segala kehidupan manusia baik dalam hubungan kepada Tuhan maupun dengan sesame manusia. Dalam novel Semua Ikan di Langit mengungkapkan pengakuan tentang ketergantungan manusia kepada Tuhan yang diungkapkan dengan bahasa yang mengandung unsur estetik, sebagai berikut.

\section{$\operatorname{Data}(1)$}

Saya belum lama memercayai beliau, tapi saya merasa bisa memercayai kemampuannya mengendarai saya dan menjaga keamanan hidup saya secara bersamaan. Maka, saya berhenti merasa cemas akan menabrak bintang atau burung kutilang, dan berfokus pada keempat kucing malang itu. (ZZ, 2017: 18)

Aspek transendensi sebagai pengakuan tentang ketergantuan manusia kepada Tuhan dapat ditemui pada kutipan di atas. Melalui kutipan data (1) diketahui bahwa manusia sebagai makhluk 
yang meyakini dan mempercayai kekuasaan serta keberadaan Tuhan meletakkan segala urusan dan berserah diri kepada Tuhan terkait dengan kehidupannya di bumi ini. Karya sastra profetik berusaha mengungkapkan fenomena manusia dengan nilai estetika serta menampilkan manusia untuk selalu mengingat Tuhan, mengingatkan keberadaan manusia dihadapan Tuhan dan kesediaan manusia menerima petunjuk Tuhan (Desiana \& Fuad, 2017; Hadi WM, 2004)

Manusia sudah sewajarnya menyerahkan dan mempercayai sepenuhnya segala takdir dan kehidupannya kepada Allah karena adanya keyakinan dalam diri makhluk beragama bahwa Allah mampu mengendalikan segala keadaan dan kondisi manusia dengan rencana terbaik, seperti pada kutipan saat bis mempercayai Beliau dalam urusan mengendarai sekaligus menjaga keselamatannya. Hal tersebut, menunjukkan bahwa kepercayaan dan keyakinan pada Allah mengikat manusia untuk selalu bergantung kepada Allah. Wujud dari ketergantungan manusia kepada Tuhan juga diungkapkan dalam kutipan lainnya, sebagai berikut.

\section{Data (2)}

Beliau juga sepertinya menyadari perasaan saya. Saya mencoba menghilangkannya karena tidak ingin membuat Beliau tersinggung- saya takut sekali., membayangkan Beliau berpikir bahwa saya tidak senang berjalan-jalan dengannya, dan akhirnya meninggalkan saya untuk selamanya. Tapi, rindu itu tidak bisa disuruh-suruh. Kalau sudah datang, dia maunya malas-malasan saja, sampai bosan sendiri dan pergi sendiri.

Akan tetapi, kerika Baliau mendengar, Beliau bukan hanya mendengar. Ketika Beliau mendengar, Beliau mendengar. (ZZ, 2017: 80)

Kutipan data (2) menunjukkan manusia dalam kehidupannya di muka bumi selalu memiliki persoalan dan masalah. Dalam penyelesaian masalah, manusia harus selalu melibatkan Allah agar memperoleh jalan keluar dan solusi yang terbaik. Oleh sebab itu manusia sering memanjatkan doa, meminta pertolongan, memohon perlindungan, dsb yang semuanya ditujukan kepada Allah. Melalu kutipandata (2) menggambarkan bahwa Allah selalu mendengar permohonan, keluhan, pertolongan bahkan pengampunan.

Melalui sifat mendengar atau As Samii telah banyak diungkapkan dalam Al quran Asy Syrura ayat 11 yang artinya : "Tidak ada sesuatupun yang serupa dengan Dia, dan Dialah yang maha mendengar lagi maha melihat". Kandungan dari ayat ini bermakna bahwa Allah mampu mendengar setiap bahasa yang dekat atau jauh bahkan yang tidak diucapkan sekalipun. Kemudian 
Allah juga memiliki kuasa untuk mengabulkan setiap permohonan, pertolongan bahkan pengampunan dari hambanya.

Realitas ketergantungan manusia ini merupakan sebuah proses transendental yang dihadirkan melalui simbol-simbol dalam karya sastra yang diungkapkan dari imajinasi pengarang. Teks yang memuat makna seringkali merupakan hasil respons terhadap realitas sosial yang mengandung pesan universal dan makna transendental (Sugiarti, 2016). Berdasarkan hal tersebut melalui di atas tokoh mengalami kesadaran akan sifat Beliau yang selalu mendengar, sehingga muncul ketergantungan untuk selalu berbicara kepada Beliau. Melalui pemaparan tersebut dapat dimaknai bahwa berbicara kepada Allah dapat dimaknai dengan kegiatan beribadah atau berdoa, yang membuat manusia. Adapun aspek transendensi yang terdapat dalam novel diwujudkan dalam kutipan sebagai berikut.

\section{Data (3)}

\section{Beliau memberikan saya kebahagiaan.}

O! Beliau yang baik hati! Mungkin bagi Beliau, sebutan untuknya memang tidak jadi masalah. Beliau adalah Beliau. Tidak masalah bagaimana caranya dan apa bentuknya: Bagi Beliau, yang penting adalah menyebut dan mengingat dirinya, dan terus menyayanginya. Dan sebagai pengganti waktu yang saya gunakan untuk menyebutnya namanya, mengingat dirinya, dan tak berhenti menyayanginya, Beliau akan mengisi saya dengan kabahagiaan; seperti bus kain berisi bulir-bulir cahaya di dasbor itu.

Ah dengan Beliau yang seperti itu, Bagaimana mungkin saya berhenti menyayanginya (ZZ, 2017: 9192)

Setiap makhluk menginginkan rasa bahagia dan kegembiraan yang berkepanjangan, sementara semua itu hanya dapat diberikan oleh Tuhan. Perasaan bahagia yang berkepanjangan itulah yang membuat manusia atau makhluk lainnya merasa memiliki ketergantuan kepada Tuhan. Ketergantungan tersebut seakan membuat manusia senantiasa berlomba-lomba mendapatkan kesenangan atau kebahagian tersebut. Sementara timbal balik yang harus dilakukan kepada Tuhan yaitu berupa pengakuan kepada Tuhan dengan sikap menyebut namanya, mengingat dirinya dan tak berhenti menyayanginya. Sikap tersebut sesuai dengan kutipan data (3) novel di atas.

Kutipan data (3) menunjukkan bahwa nilai transendensi yang terdapat dalam sastra profetik dapat memberikan kesadaran ketuhanan kepada manusia. sastra profetik berpotensi membentuk manusia unggul dan berwawasan global dengan menyeimbangkan dimensi spiritual dan sosial (Sugiarti, 2016). Berdasarkan hal tersebut maka aspek transendensi dalam karya sastra dapat 
memberikan arahan atau pedoman untuk menyadarkan manusia akan hakikat dirinya di muka bumi ini yang selalu bergantung kepada Tuhan dalam berbagai aspek kehidupan.

\section{Ada Perbedaan Mutlak Antara Tuhan Dan Manusia}

Seluruh ajaran Agama mengajarkan kepada umat manusia bahwa terdapat suatu dzat yang memiliki kekuasaan melebihi batas kemampuan manusia dan memiliki perbedaan mutlak, sehingga manusia harus memiliki perasaan patuh dan tunduk kepada dzat tersebut. Dalam Agama Islam juga menyebutkan bahwa seluruh alam semesta ini adalah ciptaan Allah, sehingga manusia adalah salah satu makhluk ciptaan Allah yang harus selalu beriman kepada-Nya. melalui konsep tersebut sudah tampak jelas bahwa Tuhan dan manusia memiliki perbedaan yang mutlak. Aspek transendensi ini juga diungkapkan dalam novel Semua Ikan di Langit karya Ziggy Zezsyazeoviennazabrizkie, yaitu sebagai berikut.

\section{Data (4)}

Saya tidak bisa melakukan apa-apa. Tapi Beliau, untungnya, mendengar. Seperti biasa, Beliau mendengar. Beliau mendengar semua kata-kata yang tidak diucapkan. Beliau memikirkannya, mempertimbangkannya, lalu memutuskan sesuatu.

Sesuatu itu, kali ini, adalah: untuk membuat saya berhenti merasa cemas.

Ah, Beliau yang baik. Beliau bisa melakukan apa saja yang beliau inginkan di dunia,tapi Beliau tetap mau saja memilih untuk melakukan sesuatu supaya bisa menyenangkan orang gendut yang tidak ada artinya seperti saya ini. (ZZ, 2017: 115)

Melalui satuan cerita data (4), digambarkan bahwa Allah memiliki kekuasaan sehingga dapat melakukan apa saja di dunia Manusia sebagai makhluk Allah tidak perlu cemas dan gelisah atas takdir dan ketetapan yang sudah direncakan Allah, karena berkat keyakinan yang teguh akan membuahkan hasil yang positif dan baik. Allah memiliki ketetapan mutlak terhadap kehidupan manusia. Takdir dapat dikatakan sebagai salah satu sifat Allah yang mampu melakukan apa saja yang dikehendaki-Nya, karena kedudukan manusia di dunia dan diakhirat tergantung dari ketetapan Allah sebelum manusia lahir ke dunia ini (Sulidar, Ardiansyah, \& Prabowo, 2017). Berdasarkan pemaparan tersebut, maka tampak dengan jelas Tuhan dan manusia memiliki perbedaan yang mutlak, yaitu sebagai pencipta dan makhluk yang diciptakan. Pada data lain juga diungkapkan mengenai perbedaan mutlak antara Tuhan dan manusia, adapun kutipan data tersebut sebagai berikut. 
$\operatorname{Data}(6)$

... Chinar menjelaskan: "Di dalam telur-telur itu adalah jiwa manusia, hewan dan tumbuhan, dan beberapa jenis lainnya yang tidak begitu bisa dijelaskan dengan kategori itu - kuman, atau pegal linu, misalnya. Di bawah dedaunan saya, mereka mendengar cerita-cerita yentang kehidupan, kematian, tentang Beliau, tentang segalanya, hm, hm. Kalau mereka sudah cukup banyak mendengar, Beliau akan menjahitkan cerita hidup mereka dari saat mereka keluar dari ibu mereka, sampai mereka kembali lagi kepada Beliau, hm, hm.

Jadi, gambar-gambar yang ada di buntelan itu adalah kisah hidup masing-masing jiwa.

"Ya," Kata Chinar. "Beliau suka membuat cerita. Kadang-kadang ceritanya sedih, kadang-kadang bahagia.... Hm! Hm! Tapi, menurut saya semuanya bagus, hm, hm..... (ZZ, 2017: 130)

Tuhan memiliki perbedaan mutlak dengan manusia, khususnya dalam hal penciptaan. Sebagai makhluk beragama, manusia harus meyakini bahwa Allah merupakan dzat yang menciptakan seluruh alam semester beserta segala isinya. Pengarang memiliki kemampuan untuk memanfaatkan imaji dan memadukan dengan bahasa yang indah dengan mumpuni. Pengarang melalui kutipan di atas menggambarkan bahwa Allah memiliki kemampuan menjadi pengatur sekaligus pencipta manusia dengan segala ketentuan dan takdir yang terbaik untuk manusia. Takdir manusia berupa seperti pada kutipan berupa kisah hidup manusia yang meliputi peristiwa yang terjadi pada waktu dan tempat tertentu sesuai dengan pencatatan yang telah ditentukan Allah. Pecatatan seluruh takdir manusia terdapat di dalam lauhl mahfuz yang sifatnya tidak akan berubah, kecuali dengan kehendak Allah (Sulidar et al., 2017).

\section{Pengakuan Akan Adanya Norma-Norma Mutlak Dari Tuhan Yang Tidak Berasal Dari Akal Manusia}

Manusia dikaruniai akal pikiran yang berfungsi mempelajari hal-hal yang berkaitan dengan penunjang kehidupan, sehingga membedakan dengan makhluk lainya yang ada di muka bumi. Akan tetapi, akal manusia dibatasi oleh penalaran yang hanya bersifat material, artinya beberapa hal yang tidak berwujud terkadang tidak mampu dinalar dengan baik bahkan dianggap mustahil. Adapun kutipan dalam novel Semua Ikan di Langit yang mengandung aspek pengakuan norma-norma Allah yang tidak berasal dari akal manusia yaitu sebagai berikut.

\section{$\operatorname{Data}(7)$}

Beliau membuat banyak jahitan lagi setelahnya: Ratusan bonek beruang aneka warna dengan pita, kancing, dan mutiara palsu. Ada yang sangat bagus, yang kaki dan tangannya bisa bergerak-gerak 
berputar-putar. Ada yang beliau buat tanpa maka, atau tanpa sebelah telinga, atau kehilangan kaki atau tangan. Ada yang dihias dengan pakaian rapi, atau obrasan berbentuk cantik. Ada yang sengaja beliau buat kotor. Ada yang beliau beri aroma kue yang sedang dibakar, atau aroma percikan air jeruk, atau aroma biji vanilla yang harum dan pekat. Tapi semuanya, yang bagus dan yang jelek, yang busuk dan yang harum, diisi ikan julung-julung dan dikirim menuruni langit, terus, menuju Bumi. (ZZ, 2017: 38)

Kutipan satuan cerita data (7) di atas dapat dimaknai sebagai proses pengabulan doa manusia sebagai bentuk rasa sayang dari Allah. Allah memberikan kasih sayang kepada manusia dengan cara yang unik, ada yang dengan hal yang membahagiakan, menyedihkan atau menyakitkan. Itu semua bermula dari ketetapan mutlak Allah yang tidak dapat dipahami oleh manusia secara naluri, karena pada hakikatnya Allah maha mengetahui apa-apa yang terbaik untuk makhluknya. Pengarang dengan daya imajinasi mengungkapkan rezeki dan ujian yang diperoleh manusia melalui penggambaran pemberian boneka dengan berbagai bentuk wujud yang bervariasi.

Allah memiliki sifat pemurah atau ar-rahman yang merupakan rahmat dari Allah yang besifat wujud dan dilimpahkan kepada orang-orang tertentu dengan tujuan memberikan hikmah atau pengampunan. (Haryadi, 2012). Rahmat ini merupakan norma atau ketetapan dari Allah kepada seluruh makhluknya dengan tujuan tertentu. Selain pada data tersebut, terdapat kutipan lain yang menunjang data mengenai pengakuan norma Allah yang tidka berasal dari penalaran manusia, adapun data tersebut sebagai berikut.

\section{$\operatorname{Data}(8)$}

.... Bahkan ikan yang tidak pernah bicara, akhirnya bicara, demi anak laki-laki itu, huh! Dia Cuma mau ditolong oleh Beliau, huh! Lagi pula, kalau Beliau tidak menolongnya, mungkin berarti dia memang harus terbakar dan jadi ikan bersama beliau, huh! Tidak buruk juga, Huh!

Nah, Beliau menyukai anak ini, tapi belum saatnya dia menjadi ikan, huh! Jadi, Beliau datang dan menyuruh api untuk berhenti menjadi panas, huh! Api menuruti Beliau, tentu saja karena api adalah anak yang baik, huh!.... (ZZ, 2017: 198-199)

Kutipan data (8) di atas memiliki kemiripan cerita dengan Nabi Ibrahim. Dalam kisah rasul dan Nabi, cerita Nabi Ibrahim memang sudah dikethui secara umum oleh masyarakat. Nabi Ibrahim diceritakan akan dihukum dengan cara dibakar atas kesalahannya menghancurkan berhala dan dianggap meremehkan Tuhan Raja Namrud. Akan tetapi, berkat kuasa dan keuatan Allah maka Nabi Ibrahim 
dikaruniai mukjizat berupa kebal terhadap panasnya api, sehingga tubuh beliau tidak terbakar api bahkan tidak measakan panas sedikitpun.

Melalui kutipan data dan kisah Nabi Ibrahim menunjukkan bahwa Allah memiliki keuatatan dan norma-norma yang tidak dapat diterima oleh akal manusia. Melalui penalaran manusia api yang memiliki sifat panas akan menghantarkan sifat panasnya pada benda yang menyentuhnya, termasuk tubuh manusia. Tetapi, berkat kuasa dan kehendak Allah maka api dirubah menjadi dingin dan tidak membakar sedikitpun dari tubuh nabi Ibramin. Mukjizat nabi Ibramin ini juga terdapat dalam Al quran pada surah Al-Anbiya ayat ke 69 yang artinya "Hai api menjadi dinginlah dan menjadi keselamatanlah bagi Ibramhim”.

Mukjizat berasal dari bahasa Arab a'jaza-yu'jizu-i’jaz yang berarti melemahkan atau menjadikan tidak mampu. Mukjizat merupakan sesuatu luar basa yang bersifat universal, temporal dan lokal yang terjadi pada Nabi sebagai bukti kenabian dengan cara menghilangkan keraguan terhadap Nabi. (Abdurrahman, 2016). Berdasarkan hal tersebut, maka salah satu mukjizat yang terjadi pada nabi Ibrahim merupakan hal luar biasanya yang tidak dapat dinalar oleh akal manusia, karena berasal dari normanorma Allah yang hanya diberikan kepada para nabi dan rasul Allah.

\section{SIMPULAN}

Berdasarkan hasil penelitian dan pembahasan daapat disimpulkan bahwa aspek transendensi dalam karya sastra merupakan sebuah wujud pemahaman kemanusiaan yang berada di muka bimi yang tidak terlepas dari kesadaran manusia dari mana ia berasal. Berdasarkan penelitian aspek transendensi dalam novel semua ikan di Langiat mengungkapkan tiga unsur utama. Pertama pengakuan tentang ketergantungan manusia kepada Tuhan yang ditandai dengan aspek (1) keyakinan dan kepercayaan pada Allah, (2) Allah yang maha mendengar, dan (3) Allah maha pengasih lagi maha penyayang. Kedua ada perbedaan mutlak antara Tuhan dan manusia meliputi aspek, (1) Allah memiliki kuasa untuk menciptakan alam semesesta beserta isinya termasuk manusia dan makhluk lainnya, dan (2) mampu melakukan apa saja di mukabumi. Ketiga pengakuan adanya norma-norma mutlak dari Tuhan yang tidak berasal dari akal manusia meliputi aspek (1) Mukjizat pada Nabi dan Rasul Allah, dan (2) memberikan rahmat kepada seluruh makhluk-Nya. Kedua, ada perbedaan mutlak antara Tuhan dan manusia yang ditandai dengan pengakuan keterbatasan diri manusia serta kesempurnaan yang dimiliki Tuhan. Ketiga, pengakuan akan adanya norma-norma mutlak dari Tuhan yang tidak berasl dari akan manusia melalui kepatuhan dan ketaatan manusia terhadap ketetapan dari Tuhan. 


\section{SARAN}

Ada beberapa saran yang dikemukakan berdasarkan paparan di atas.

1. Secara praktis, artikel ini bisa menjadi referensi dalam bidang sastra, khususnya berkenaan dengan nilai profetik yang ada pada sebuah karya sastra.

2. Secara teoritis, artikel ini menjadi sumbangan ilmu pngetahuan serta bisa diaplikasikan dalam kajian sastra yang bermanfaat bagi peniliti selanjutnya.

\section{DAFTAR RUJUKAN}

Abdurrahman. (2016). Mukjizat al-qur'an dalam berbagai aspeknya. Pusaka Jurnal Media Kajian dan Pemikiran Isla , 8, 68-85.

Desiana, Y., \& Fuad, M. (2017). Nilai-Nilai Realitas Profetik Novel Bulan Terbelah Di Langit Amerika Dan Pengembangan. Jurnal Simbol Bahasa, Sastra Dan Pembelajarannya, 1(1), 110.

Efendi, A. (2012). Realitas Profetik Dalam Novel Ketika Cinta Bertasbih Karya Habiburrahman ElShirazy. Litera Jurnal Penelitian Bahasa, Sastra, dan Pengajarannya, Volume.11, No.1, hlm. 72-82.

Garaudy, Roger. (2000). Les Mythes Fondaterurs de la Politique israelienne. (Maulida Khiatuddin). Depok: Insani Pres (Original work published 1998)

Hadi W.M, Abdul. (2004). Hermeneutika, Estetika, dan Religiusitas Esai-esao Sastra Sufisti dan Seni Rupa. Yogyakarta: Matahari.

Haryadi. (2012). Sufisme dalam Syair Hamzah Fansuri. Litera Jurnal Penelitian Bahasa, Sastra, dan Pengajarannya, Volume.11, No.2, hlm. 243-255.

Kuntowijoyo. 2005. Maklumat Sastra Profetik: Kaidah, Etika dan Struktur Sastra. Yogyakarta: Multi Persindo.

Sugiarti. (2015). Simbol Politik dan Keculasan Politik dalam Novel Gelonggong Karya Janedi Setiyono. Telangkai Jurnal Bahasa dan Sastra,Tahun Ke-9, No.1, Januari 2015, hlm.1-9.

-------, (2016). Kesadaran Ketuhanan Tokoh Utama Dalam Kumpulan Cerpen Ketika Mas Gagah Pergi Dan Kembali Karya Helvy Tiana Rosa. Kembara Jurnal Keilmuan Bahasa, Sastra Dan Pengajarannya, Volume. 2, April 2016, hlm. 90-97.

Sulidar, Ardiansyah, \& Prabowo, Y. (2017). Wawasan Tentang Taqdir dalam Hadis. At-Tahdis: Journal Of Hadist Studies, Volume. 1, No.2, hlm. 5-21. 
Wulananda, Ramadhaniar., Saryono, Djoko., dan Suwignyo, Heri. (2016). Estetika Profetik Novel Muhammad: Lelaki Penggenggam Hujan Karya Tasaro G.K sebagai Sumber Pendidikan Karakter. Jurnal Pendidikan: Teori, Penelitian, dan Pengembangan. Volume. 1, No. 7, Juli 2016, hlm. 1350-1363

Zezsyazeoviennazabrizkie, Ziggy. (2017). Semua Ikan di Langit. Jakarta: PT. Gramedia. 